\section{DINOSAUR WORLD}

\section{The Age of the Dinosaurs}

By Bjorn Kurtén. (World University Library.) Pp. 255. (Weidenfeld and Nicolson: London, 1968.) 14s. paperback; 30s. hardback.

Dr Kurtín has set out to re-create the reptile-dominated world of Mesozoic times, and has succeeded very well. The first chapter is introductory, outlining the growth of our understanding of evolution, of the fossil record and of geological processes (including a good, up to date account of the theory of continental drift). The stage is set by a brief survey of evolution during the Palaeozoic, with special emphasis on the vertebrates. The largest section of the book, more than 100 pages, is devoted to an account of the vertebrates of the Mesozoic, and more than half of this is taken up by the dinosaurs themselves. Other chapters deal with the flora and invertebrates of the Mesozoic, with the geography of the Jurassic and Cretaceous, and with the mammals of the Cacnozoic. The book is therefore not merely an account of the dinosaurs themselves, but deals also with many other aspects of the world which they inhabited.

A lecturer in palaeontology at Helsinki, Kurtén writes extremely well, and deals with the Mesozoic vertebrates as living creatures. He explains clearly the problems which faced them and the adaptations which evolved to cope with these. The accompanying photographs are particularly well chosen, and are far from being a repetition of those already over-familiar from many appearances in similar books. The drawings and diagrams are also mostly good-except for the geological map of the British Isles, which is almost incomprehensible and quite inadequate as a companion to the excellent relevant part of the book.

Despite all its virtues, it is not at all clear what audience this book is designed for. The publishers state that the World University Library aims "to provide authoritative introductory books for university students which will be of interest also to the general reader". It is a little difficult, however, to see how a book which concentrates on the Mesozoic vertebrates can form a natural introductory textbook, because most university courses deal with the complete history of the group. The general reader, on the other hand, attracted by the title, may well be disappointed to find that only a fifth of the book deals with the dinosaurs themselves. I hope that these mis givings prove to be ill-founded, for Kurtén's book deserves to be read.

BARRY COX

\section{BIOLOGY OF SPACE RESEARCH}

\section{Life Sciences and Space Research VI}

Edited by A. H. Brown and F. G. Favorite. (Procecdings of the Open Meeting of Working Group V of the Tenth Plenary Meeting of COSPAR, London, July 27-28, 1967.) Pp. viii + 197. (North-Holland: Amsterdam, 1968.) 105s.

THE annual plenary sessions of the International Council of Scientific Union's Committee on Space Research provide a forum for the exchange of information on the biological aspects of space research. The first of this collection of the papers given at the tenth meeting is a brief summary by Berry of the physiological data collected in relation to the Mercury and Gemini orbital flight programmes. $\mathrm{He}$ compares the cardiovascular changes which have occurred in space flight with those produced by bed rest, and documents the increase in the size and fragility of the red cells and the associated 20 per cent reduction of red cell mass which occurred in the eight-day flights. 'The physiological information obtained during extravehicular activity is also presented and discussed.
The following section, which forms one-sixth of the book, consists of several papers relating to the physiological aspects of life support systems, in particular the use of cultures of algae as gas exchangers and sources of food in a closed system. Thoso papers given by workers from tho Soviet Union include an account of a successful thirty-day experiment in which carbon dioxide was removed from, and oxygen added to, the atmosphere of a sealed compartment containing human subjects by a culture of micro-algae. The gas exchange of the subjects was matched to that of the micro-algae by controlling the diet of the former.

Almost one-third of the book is devoted to papers which discuss the effects of extreme environments, including ionizing and ultraviolot radiation, weightlessness and very low temperature, on living organisms. Grandpierre and Chatelier give an account of the psychomotor and EEG responses of Macaque nemestrina to a ten minute exposure to weightlessness produced by a rocket flight. Young and Tremor describe experiments in which fertil. ized frog eggs were exposed to the weightless state for periods of up to four days in Gemini 12. No abnormal effects were noted, but unfortunately the most sensitive first cleavage occurred before orbital flight began.

Six papers devoted to the probability of finding life on other planets, methods of detection of life and the risks of contamination of other planets by organisms carried from Earth by spacecraft form the last section of the book. Hawrylewicz and his colleagues have shown that Staphylococcus aureus can survive in a gaseous environment which simulates that of Mars, provided that moisture and organic material are present. Imshenetsky and coworkers from Moseow describe an experimental evaluation of methods of detecting extraterrestrial life which use the demonstration of enzymatic activity or cell growth in a nutrient medium. They used changes of $p \mathbf{H}$ of the growth medium, the absorption of ultraviolet light, the decomposition of ${ }^{14} \mathrm{C}$ labelled glucose, and the detection of iron porphyrin containing compounds and of ATP.

Many different aspects of biological researeh appear in this volume. Some specialists have still not appreciated the importance of presenting their work in a form which can be understood readily by the general physiologist and by specialists in other branches of the life sciences. The absence of adequate figure captions and labelling of axes of graphs in certain papers detracts from their value.

J. Ernsting

\section{BRAIN BARRIERS}

\section{Brain Barrier Systems}

Edited by Abel Lajtha and Donald H. Ford. (Progress in Brain Research, Vol. 29.) Pp. xv +552. (Elsevier: Amsterdam, London and New York, 1968.) $230 s$.

THIs book commands attention for soveral reasons. Not only is it extremely well printed and bound, but its subject matter is timely and provocative and no doubt will have a wide circulation.

There are inevitably some of the deficiences to be found in books that are basically a compilation of the reports and discussions that took place at a symposium. The direct relevance of some of the papers may have become lost in the post-symposium editing and/or "polishing up" of the manuscripts before publication. It is difficult, for example, to see the rolevance of the excellent paper by Deul, Haisma and Breemen on the ganglioside binding of serotonin, and the subsequent discussion is not helpful. A similar comment can be made on part of the extremely interesting paper by Tennyson et al. on the cholinesterase in the nervous system, much of which refers to dorsal root ganglia and sympathetic neurones. 